\title{
Smoking habits of long-term survivors of surgery for lung cancer
}

\author{
G DAVISON, M DUFFY \\ From Broomfield Hospital, Chelmsford, Essex
}

\begin{abstract}
The smoking habits of 52 patients who had survived more than five years after treatment for lung cancer were studied. Fifty-six per cent had stopped smoking before operation but this was not an early feature of the disease. No patients smoked in the immediate postoperative period but $48 \%$ became regular smokers again, usually within a year of the operation. Those who had stopped before, rather than after, their operation were more likely to remain nonsmokers. Doctors were usually unsuccessful in persuading those patients who had restarted after surgery to stop smoking. Patients undergoing surgery for lung cancer should be advised to stop smoking before the operation. Those in whom resection is successful should receive regular support and encouragement from doctors, especially in the first postoperative year, to continue as nonsmokers.
\end{abstract}

\begin{abstract}
Although some patients smoke after resection of a lung cancer, ${ }^{1}$ little is known about the full smoking habits, both before and after operation, of long-term survivors with this disease. Second primary lung cancers diagnosed after resection of the first have been reported and some of these patients continued to smoke. ${ }^{2}$ We have studied whether and when long-term surgical survivors with lung cancer stopped smoking and also the amount they smoked both before and after operation. The advice of doctors, when it was given, and the influence it had on smoking have also been investigated.
\end{abstract}

\section{Methods}

Fifty-two patients who had survived at least five years after resection of a lung cancer were studied. Twenty-eight patients had survived five to 10 years, 14 between 10 and 15 years, seven between 15 and 20 years, and three over 20 years. Thirty-eight patients had squamous cell carcinomas, 10 anaplastic carcinomas, three adenocarcinomas, and one an oat cell carcinoma. Twenty-six patients had pneumonectomies, 24 lobectomies, and two segmental resections. Forty-seven of the patients were operated on at Broomfield Hospital by one surgeon (G Flavell); 34 of these were followed up at the

Address for reprint requests: Dr Anthony G Davison, The Brompton Hospital, Fulham Road, London SW3 6HP. chest clinic at his hospital; six were followed up in other clinics in the same hospital; seven were followed up at other centres, including thoracic surgery outpatients at The London Hospital. The latter group of patients were known to have all received forceful advice to stop smoking (by G Flavell personally). Five patients had operations at other centres and were subsequently followed up at this hospital. We therefore expected, before the study started, because of the various follow-up arrangements that the patients would probably have had variable advice on smoking. Information about smoking habits and the medical advice given to patients was obtained from the medical notes and by questionnaires. Statistical analysis was by Student's $t$ test and chi-square test with Yates's correction, and $p<0.01$ was taken as significant.

\section{Results}

Fifty $(96 \%)$ of the patients were smokers before operation. Forty-five smoked only cigarettes, four only a pipe, and one both cigarettes and a pipe. Twenty-eight $(56 \%)$ of the smokers stopped smoking preoperatively, but 19 (68\% of those who stopped smoking) only stopped in the four weeks leading up to their operation (table 1).

No patients smoked in the immediate postoperative period; however three restarted within a week of their operation (table 2). Twenty-seven (54\% of preoperative smokers) have smoked since their 
Table 1 Number of patients who stopped smoking at various time intervals before their operation, and number in each interval who did not smoke regularly postoperatively

\begin{tabular}{|c|c|c|c|c|c|c|c|}
\hline Time intervals before operation & $\begin{array}{l}\text { Less than } \\
\text { l week }\end{array}$ & $\begin{array}{l}1-2 \\
\text { weeks }\end{array}$ & $\begin{array}{l}2-4 \\
\text { weeks }\end{array}$ & $\begin{array}{l}\text { I-2 } \\
\text { months }\end{array}$ & $\begin{array}{l}2-6 \\
\text { months }\end{array}$ & $\begin{array}{l}\text { Over } \\
2 \text { years }\end{array}$ & Total \\
\hline $\begin{array}{l}\text { Number of patients who stopped smoking before } \\
\text { the operation }\end{array}$ & 8 & 5 & 6 & 3 & 2 & 4 & 28 \\
\hline $\begin{array}{l}\text { Number in each interval who did not smoke } \\
\text { regularly postoperatively }\end{array}$ & 6 & 2 & 4 & 3 & 2 & 4 & 21 \\
\hline
\end{tabular}

Table 2 The various times after their operation when those who smoked regularly again restarted

\begin{tabular}{|c|c|c|c|c|c|c|c|c|}
\hline Time postoperatively & $\begin{array}{l}\text { Less than } \\
\text { l week }\end{array}$ & $\begin{array}{l}1 \text { week- } \\
1 \text { month }\end{array}$ & $\begin{array}{l}1 \text { month- } \\
3 \text { months }\end{array}$ & $\begin{array}{l}3 \text { months- } \\
6 \text { months }\end{array}$ & $\begin{array}{l}6 \text { months- } \\
1 \text { year }\end{array}$ & $\begin{array}{l}1 \text { year- } \\
2 \text { years }\end{array}$ & $\begin{array}{l}\text { Over } \\
2 \text { years }\end{array}$ & Total \\
\hline Number of patients restarting smoking & 3 & 4 & 3 & 4 & 5 & 3 & 2 & 24 \\
\hline
\end{tabular}

operation. Twenty-four became regular smokers (table 2) with three smoking more than, 11 the same as, and 10 less than before operation. Three patients have had occasional cigarettes. Seventy-nine per cent of those who became regular smokers again did so within a year of their operation (table 2). The longest gap postoperatively before restarting was three years. The number of patients not smoking regularly postoperatively was greater among those who had stopped smoking preoperatively ( 21 of 28 ) than among those who only stopped in the immediate postoperative period (five of 22) (chi-square with Yates's correction $\mathrm{p}<0.001)$. Those who smoked regularly postoperatively smoked less (24/ day) preoperatively than those who gave up (26/ day); however, the difference was not significant $(t$ test $\mathrm{p}<0.5)$. Six $(23 \%)$ of those who became regular smokers postoperatively subsequently stopped. They stopped smoking three, five, eight, 12, 13, and 15 years after surgery.

Fifty per cent of the smokers had been given advice about smoking by doctors. This information was usually obtained from questionnaires because advice on smoking was rarely recorded in the medical notes. Nine had been told to stop smoking preoperatively (eight by hospital doctors); three (33\%) of those became regular smokers again. Fifteen patients were given advice postoperatively (seven by hospital doctors, five by general practitioners, and three by both); 11 (73\%) of these became regular smokers again. However, in 12 cases this advice was given after the patients had started smoking regularly again, and only two of these patients subsequently stopped smoking. Five patients were advised to stop smoking both pre- and postoperatively. One patient had been advised not to stop smoking.

Six patients developed fresh lesions after the initial resection. These, were on the contralateral side of the chest to the original lesion and appeared on chest $\mathrm{x}$-ray films three, five, six, seven, 12 , and 15 years after the first operation. All the first primaries and the fresh lesions were squamous cell carcinomas. Five had further resections and are still alive (survival one to five years). There was no evidence of stump recurrence, extension of residual carcinoma of the lung, or extension in hilar lymph nodes. These lesions may have been second primary lung cancers, ${ }^{2}$ but metastases from the original tumour cannot be ruled out because the histology in both the original and fresh lesions was the same. ${ }^{3}$ All six patients were cigarette smokers, and their mean consumption (40/day) before the first operation was significantly higher than the other cigarette smokers' (23.5/day) $(t$ test $p<0.001)$. Three patients continued to smoke after their first operation (35/day) but stopped when the fresh lesion appeared five, 12, and 15 years later. They have not restarted smoking.

\section{Discussion}

It has been suggested that stopping smoking is often a symptom of respiratory illness, including lung cancer. ${ }^{4}$ However, we found that only just over half of the patients stopped smoking before resection of a lung cancer. Also this was not an early feature of the disease as the majority only stopped during the four weeks leading up to the operation. All stopped smoking for at least a short time postoperatively; however, nearly half started smoking regularly again and most of these continued as smokers. Although patients' accounts of their smoking may be misleading, ${ }^{5}$ there was good agreement between the information in the medical notes and on the questionnaires.

Medical advice can be influential in persuading patients to stop smoking. ${ }^{6}$ However, only half of the 
patients reported here had received advice about smoking. Abandoning smoking is not an easy task and it is unreasonable to add this burden to patients with lung cancer in whom no or only palliative treatment can be offered and who consequently have a very poor prognosis. Surgery, with approximately a $30 \%$ five-year survival, offers the best hope of curative treatment. ${ }^{7}$ Patients who became regular smokers after surgery generally had not stopped before their operation, usually started again in the first post-operative year, and were unresponsive to medical advice once they had restarted. Even those who only stopped smoking in the week before their operation usually continued as nonsmokers. All patients in whom potential curative treatment is planned should be encouraged to stop smoking before rather than after their operation. Stopping smoking before surgery probably also prevents post-anaesthetic complications. Those patients in whom successful resection has been possible should continue to receive regular support and encouragement from doctors, especially during the first postoperative year, to continue as nonsmokers. The prognosis in those who undergo thoracocotomy but in whom a potentially curative resection of the tumour is not possible is very poor, ${ }^{1}$ and it is inappropriate to continue to encourage these patients to stop smoking.

Abbey Smith reported 55 patients with probable second primary lung carcinomas and found that they had smoked significantly more before resection of the first primary than patients with a single primary. ${ }^{2}$ It is impossible at present to assess the role that continued smoking, after resection of the first primary, plays in the development of a second primary for two major reasons. Firstly there are considerable problems in distinguishing a metastasis of the first primary from a second primary lung cancer. ${ }^{23} \mathrm{Sec}-$ ondly many years may elapse between the initial malignant change and the diagnosis of a tumour. ${ }^{8}$ It is difficult to know whether the initial malignant change of a second primary took place before or after the resection of the first tumour; the relevance of continued smoking is therefore also difficult to assess. It may be possible to overcome these problems by studying patients with a long gap between the first primary and the fresh lesion, but very few patients have been reported with a gap of 12 years or more. ${ }^{2}$ There were two such patients in this series and both had continued as heavy smokers (40/day).

Continued smoking may influence the incidence of respiratory and cardiovascular disease in longterm survivors, and respiratory disease, excluding lung cancer, is the second most common cause of late death in these patients. ${ }^{1}$ An analysis of smoking habits should be included in reports of long-term survivors with lung cancer.

We are grateful to $\mathrm{Mr}$ G Flavell for his help and advice in the preparation of this paper. We thank the other physicians and surgeons who allowed patients under their care to be included in this study. We also thank Dr ACC Hildrey for his help and Miss T Chudleigh for typing the manuscript.

\section{References}

'Belcher JR, Rehahn M. Late deaths after resection for bronchial carcinoma. Br J Dis Chest 1979;73:18-30.

${ }^{2}$ Abbey Smith R, Nigam BK, Thompson JM. Second primary lung carcinoma. Thorax 1976;31:507-16.

${ }^{3}$ Chaudhuri MR. Independent bilateral bronchial carcinoma. Thorax 1971;26:476-80.

${ }^{4}$ Spencer Jones J. Cigarette abandonment: its significance. Br J Dis Chest 1977;71:285-8.

${ }^{5}$ Wilcox RG, Hughes J, Roland J. Verification of smoking history after infarction using urinary nicotine and cotinine measurements. Br Med J 1979;2:1026-8.

- Burt A, Thomley $\mathrm{P}$, Illingworth $\mathrm{D}$, et al. Stopping smoking after myocardial infarction. Lancet 1974;1:304-6.

${ }^{7}$ Flavell G. Conservatism in surgical treatment of bronchial carcinoma. Br Med J 1962;1:284-7.

${ }^{8}$ Geddes DM. The natural history of lung cancer. A review based on rates of tumour growth. Br J Dis Chest 1979;73:1-17. 